\title{
ACKNOWLEDGMENTS
}

For their inspiration and relentless pursuit of social change, I am indebted to the many leaders and staff of the organizations profiled in this book, particularly Marty Chen, Naresh Jain, Niraj Joshi, Ravi Krishna, Shaffi Mather, Apoorva Oza, Naveen Patidar, Vasim Qureshi, Adam Rocap, Scott Schenkelberg, and Joann Vanek. Thank you for sharing your experiences in the interest of advancing the sector, and for your time and patience with me as I shaped this project over many years.

Three extraordinary colleagues have been sparring partners on key ideas: Kash Rangan at Harvard University, Gerhard Speckbacher at the Vienna University of Economics and Business, and Paul Brest at Stanford University. A special thanks to David Gergen and Jeff Walker for encouraging this project and its vision.

Several excellent research assistants helped during different stages of this book. Vidhya Muthuram was indispensable with interviews, data collection, and early drafts of the case studies in India, going above and beyond the call of duty to track down quotes and materials. David Forte assisted with the US interviews and cases, Nashwa Khalid with graphics, and Floor de Ruijter van Steveninck with the resource appendix.

Harvard Business School supported my field research, and the Fletcher School of Law and Diplomacy gave me the space and time to write.

For their intellectual engagement and insights, I am grateful to Lehn Benjamin, Dave Brown, Julia Coffman, Peter Frumkin, Joe Galaskiewicz, Mary Kay Gugerty, Sherine Jayawickrama, Matt Lee, 
David Lewis, Johanna Mair, Chris Marquis, Mark Moore, Alex Nicholls, Len Ortolano, Woody Powell, Patricia Rogers, Christian Seelos, Steven Rathgeb Smith, Melissa Stone, Peter Uvin, and Julie Boatright Wilson.

I also wish to thank many leaders in the social sector whose work has been a constant source of motivation: Tom Adams, Clara Barby, Jonathan Bloom, David Bonbright, Jeff Bradach, Sir Ronald Cohen, Sasha Dichter, Sarah Gelfand, Lisa Jordan, Kelly McCarthy, Katherine Milligan, Mario Morino, Jeremy Nicholls, Luther Ragin, Khalil Shariff, Nan Stone, Tom Tierney, Brian Trelstad, Michael Weinstein, and Peter Wuffli.

At both the Fletcher School and the Tisch College of Civic Life at Tufts University, I am grateful to have many colleagues committed to research on social change, and to imparting our students with the global outlook and skills to be active agents of change. For their support, I thank Steven Block, Bhaskar Chakravorti, Peter Levine, and both of my deans, Admiral James Stavridis and Ambassador Alan Solomont.

A spot in my heart is reserved for my wonderful students at Fletcher, whose engagement with a draft version of this book was everything a teacher could want: incisive, constructive, and fresh. You brought joy to the classroom and to the arduous work of scholarship, and you inspire hope for the future of our precious world.

In bringing this book to fruition, I have been fortunate to work with two fantastic editors at Stanford University Press - Margo Beth Fleming, with whom I started this book, and Steve Catalano, with whom I completed it - with the able editorial assistance of Olivia Bartz, Nora Spiegel, and Sunna Juhn, project management by Charlie Clark, copyediting by Kristine Hunt, and the immensely helpful feedback from reviewers.

In the end, none of this would have been possible, or even worthwhile, without the trinity of poetry, friendship, and family. The works of Seamus Heaney and Tomas Tranströmer have been anchors. To Michel Anteby, Julie Battilana, Lakshmi Ramarajan, Marion Fremont-Smith, Jane Nelson, E. M. Shashidharan, and to your families, I am forever grateful. To Edward and Lisabeth Weisband, from 
you I have learned what it means to put love into one's teaching and art, that is, to merge the hidden and the visible in our lives. I think often about my first teacher, my late aunt Zarin, who taught my siblings and me to embrace the English language as our own, and who understood the long-term impact of early childhood education before it was formally measured. And to my siblings - Ezmina, Yasmin, Amin, and your families - thank you for always being there, rock solid and wonderful.

The word gratitude feels so inadequate for describing the all given by Maria, my wife and dearest friend. Chef extraordinaire, intellectual partner, and editorial eagle-eye are better descriptors but still don't hold a candle to you. All I can say is I promise to be your sous chef for life.

And finally, my parents Shirin and Sadrudin, who embody the spirit of social change in their daily lives, and who traversed continents, risking everything, to give their children better lives - this book is dedicated to you. 
This page intentionally left blank 


\section{MEASURING SOCIAL CHANGE}


This page intentionally left blank 